\title{
The expression of MDM2/CDK4 gene product in the differential diagnosis of well differentiated liposarcoma and large deep-seated lipoma
}

\author{
S Pilotti ${ }^{1}$, G Della Torre ${ }^{2}$, A Mezzelani', E Tamborini ${ }^{1}$, A Azzarelli ${ }^{3}$, G Sozzi ${ }^{2}$ and MA Pierotti ${ }^{2}$ \\ Departments of ${ }^{1}$ Pathology and Cytopathology, ${ }^{2}$ Experimental Oncology and ${ }^{3}$ Surgery of Soft Tissue Tumors, Istituto Nazionale per lo Studio e la Cura dei \\ Tumori, Via G. Venezian, 1-20133 Milano, Italy
}

\begin{abstract}
Summary Ordinary lipomas are cytogenetically characterized by a variety of balanced rearrangements involving chromosome segment 12q13-15, whereas well differentiated liposarcomas (WDL) show supernumerary ring and giant marker chromosomes, known to contain amplified $12 q$ sequences. The tight correlation between the presence of ring chromosomes and both amplification and overexpression of MDM2 and CDK4 genes suggests the exploration of the possibility that immunocytochemistry (ICC) might assist in the differential diagnosis of lipoma-like well differentiated liposarcomas (LL-WDL) and large deep-seated lipomas (LDSL). For this purpose, 21 cases of the former and 19 cases of the latter tumours were analysed by ICC and, according to the availability of material, by molecular and cytogenetic approaches. All lipomas displayed a null MDM2/CDK4 phenotype, whereas all LL-WDL showed MDM2/CDK4 or CDK4 phenotypes. Southern blot analysis performed on 16 suitable cases, complemented by fluorescence in situ hybridization and classical cytogenetic analysis in 11 cases, was consistent with, and further supported the immunophenotyping data. In conclusion, MDM2/CDK4 product-based immunophenotyping appears to represent a valuable method for the categorization of arguable LDSL. ( 2000 Cancer Research Campaign
\end{abstract}

Keywords: MDM2; CDK4; lipoma; liposarcoma lipoma-like; differential diagnosis

Non-subcutaneous ordinary lipomas, including subfascial and intramuscular lipomas, account for $40 \%$ of ordinary lipomas (Fletcher et al, 1996). These tumours, also called deep-seated ordinary lipomas, may achieve a large size, particularly the intramuscular ones. In these cases the differential diagnosis between large deep-seated ordinary lipoma (LDSL) and the lipoma-like subtype of well differentiated liposarcoma (LL-WDL) may be difficult due to their similar histologic characteristics and focality of nuclear atypia (Rosai et al, 1996).

Furthermore, although lipomatous tumours in the retroperitoneum are mainly represented by well differentiated liposarcomas (WDL), lipomas may also appear at this site (DeWeerd et al, 1952). Thus, it would be valuable to support histologic classification with a simple immunophenotypic procedure in arguable cases. The 12q13-15 chromosome region is complex and contains several genes that are amplified or rearranged in lipomatous tumours such as the MDM2, CDK4, SAS or CHOP and HMGI-C (High Mobility Group I-C protein) genes respectively (Smith et al, 1992; Forus et al, 1993; Khatib et al, 1993; Leach et al, 1993; Schoenmakers et al, 1995). HMGI-C gene translocations have been suggested to facilitate the development of lipomas (Schoenmakers et al, 1995; Tkachenko et al, 1997). On the other hand, $M D M 2$ and $C D K 4$ amplification and overexpression, which in turn correlate with the presence of chromosomes containing material from 12q, have been indicated as frequent in WDL (Dal

Received 16 July 1999

Revised 16 November 1999

Accepted 24 November 1999

Correspondence to: S Pilotti
Cin et al, 1993; Khatib et al, 1993; Pedeutour et al, 1993; Hunter and Pines, 1994; Nilbert et al, 1994; Pilotti et al, 1997, 1998). More recently it has also been shown that overexpression of $12 q$ sequences is a recurrent finding in WDL but not in lipoma (Mandahl et al, 1996; Szymanska et al, 1997).

Here we applied a $M D M 2 / C D K 4$ gene-product-based immunophenotypic analysis, complemented in suitable cases by molecular and cytogenetic approaches, to a series of LL-WDLs and of LDSLs for comparison purposes.

The results show that MDM2/CDK4 immunophenotyping may assist in the differential diagnosis of the two entities.

\section{MATERIALS AND METHODS}

\section{Materials}

The case material consisted of 21 cases of LL-WDL including 12 primary and nine recurrent tumours and 19 primary LDSL from patients treated at our institution between 1988 and 1997. Eleven cases had been included in a previously reported series (cases 5, 9-13, 17-21) (Pilotti et al, 1997). All cases have been reviewed in order to verify the diagnosis and select representative tumoural samples for immunophenotypic analysis. The morphologic diagnoses were confirmed in all cases following the criteria of the pathologists of the CHAMP study group (Willen et al, 1998) and the criteria of Evans (1988) updated by Mentzel and Fletcher (1995). The cases were consecutive according to the criteria of selection: histologic subtype (LL-WDL) for liposarcoma and size $(>7 \mathrm{~cm}$ in largest diameter) for lipoma.

The age and sex of the patients as well as the location, type of specimens analysed (primary, recurrence) and size of the tumours are presented in Tables 2 (LL-WDL) and 3 (LDSL). 
Table 1 Lipoma-like well differentiated liposarcomas: clinical features

\begin{tabular}{|c|c|c|c|c|c|c|}
\hline Case no. & Age/Gender & Site & Primary treatment & $\begin{array}{l}\text { Number/Time of local } \\
\text { recurrence }\end{array}$ & Treatment of recurrence & Follow-up \\
\hline 1 & $64 / F$ & Thorax wall & Resection & 2 , at 7 and 9 years & Resection + CT & NED, 1 year \\
\hline 2 & $84 / \mathrm{M}$ & Thigh & Resection & - & - & NED, 1 year \\
\hline 3 & $42 / \mathrm{M}$ & Retroperitoneum & Resection & - & - & Lost \\
\hline 4 & $36 / \mathrm{F}$ & Retroperitoneum & Resection $^{b}$ & 1 , at 1 year & Resection + RT & AWD, 2 years \\
\hline 5 & $49 / \mathrm{M}$ & Retroperitoneum & Resection $^{b}$ & 3 , at 4,6 and 9 years & Resection & AWD, 9 years \\
\hline 6 & $50 / \mathrm{M}$ & Retroperitoneum & $\mathrm{RT}^{\mathrm{a}}$ resection ${ }^{\mathrm{b}, \mathrm{c}}$ & 1 , at 1 year & $\mathrm{RT}$ + resection & NED, 2 years \\
\hline 7 & $59 / \mathrm{M}$ & Thigh & Resection $^{b}$ & 1 , at 4 years & Resection + CT & NED, 1.5 years \\
\hline 8 & $67 / \mathrm{M}$ & Retroperitoneum & Resection $^{b}$ & 1 , at 3 years & Resection & NED, 5 years \\
\hline 9 & $56 / F$ & Retroperitoneum & Resection & - & - & NED, 4 years \\
\hline 10 & $57 / F$ & Retroperitoneum & Resection ${ }^{b}$ & 1 , at 3 years & Resection & lost \\
\hline 11 & $64 / \mathrm{M}$ & Retroperitoneum & $\mathrm{CT}^{\mathrm{a}}$ resection ${ }^{\mathrm{b}}$ & 2 , at 2 and 5 years & Resection + RT & AWD, 5 years \\
\hline 12 & $46 / F$ & Retroperitoneum & Resection ${ }^{b}$ & 2 , at 3 and 6 years & Resection + CT + RT & AWD, 9 years \\
\hline 13 & $51 / F$ & Retroperitoneum & Resection $^{\mathrm{b}}$ & 1 , at 3 years & Resection & NED, 6 years \\
\hline 14 & $62 / \mathrm{M}$ & Thigh & Resection & - & - & NED, 2 years \\
\hline 15 & $72 / \mathrm{M}$ & Thigh & Resection & 2 , at 4 and 7 years & Resection & NED, 9 years \\
\hline 16 & $52 / \mathrm{M}$ & Shoulder & Resection & - & - & lost \\
\hline 17 & $66 / \mathrm{M}$ & Thigh & Resection & 3 , at 5,12 and 13 years & Resection + CT & AWD, 2, 5 years \\
\hline 18 & $45 / F$ & Arm & Resection & - & - & NED, 1,5 years \\
\hline 19 & $28 / \mathrm{M}$ & Thigh & Resection & - & - & NED, 9 years \\
\hline 20 & $26 / F$ & Buttock & Resection & - & - & NED, 9 years \\
\hline 21 & $44 / F$ & Pelvis & Resection & 1 , at 1 years & $\mathrm{CT}$ & lost \\
\hline
\end{tabular}

$\mathrm{RT}=$ radiotherapy; CT = chemotherapy; NED = no evidence of disease; AWD = alive with disease. ${ }^{a}$ For details see text. ${ }^{\mathrm{b} P} \mathrm{Primary}$ tumour resection performed elsewhere. "Synchronous renal carcinoma.

Histologically, the lipoma-like component constituted $100 \%$ of the tumour in 16 out of 21 LL-WDLS including primaries and recurrences. In three retroperitoneal cases a sclerosing subtype component constituted from $20 \%$ (case no. 3 ) to $30 \%$ (cases 4 and 5 ) of the total of sampled tumours respectively, and in two nonretroperitoneal tumours (cases 1 and 7) this component corresponded to less than $20 \%$. In two cases radiotherapy (case no. 6) and chemotherapy (case no. 11) were performed before surgical resection of tumour samples for study.

\section{Immunocytochemistry, karyotyping and Southern blot analysis}

Immunocytochemistry, karyotyping and Southern blot analysis were carried out as previously described (Pilotti et al, 1997, 1998). For immunostaining analysis from 2-8 LL-WDLs samples (for details see Table 2) and all samples of LDSLs were processed.

Suitable material for molecular analysis was available in nine out of 21 (42.8\%) LL-WDLs and in seven out of $19(36.8 \%)$ LDSLs. The material suitable for classic cytogenetic analysis accounted for three out of 21 and two out of 19 cases in the two groups respectively.

For Southern blotting, DNA was digested with the restriction enzyme KpnI. Radiolabelled probes were: a 258-nucleotide MDM2 genomic fragment amplified by PCR with primers within exons 2 and 3 of the gene (Zauberman et al, 1995), a 534nucleotide $C D K 4$ genomic fragment generated by polymerase chain reaction (PCR) using the primers described by Khatib et al. (1993), and a PCR-generated TP53 genomic fragment spanning nucleotides $13040-13450$ of the gene. Hybridization with each probe resulted in a single band, which was of about $23 \mathrm{~kb}$ for the $M D M 2$ gene, $1.5 \mathrm{~kb}$ for the $C D K 4$ gene, and about $12 \mathrm{~kb}$ for TP53.

\section{Fluorescence in situ hybridization}

Interphase fluorescence in situ hybridization (FISH) analysis was carried out on cryopreserved cytologic scrapings of the surgical specimen. Each slide was hybridized with the biotinylated probe Amplification unit probe 12q13 (Li Biomedical Corporation) corresponding to the amplicon MDM2, SAS and GLI genes. Hybridization was performed according to Lichter et al (1990), Mezzelani et al (1996) and the manufacturer's recommendations. The sample was scored as amplified when the single nuclei showed more than two signals. Metaphase FISH analysis was performed using whole chromosome 12 and 6 paintings (CAMBIO, Cambridge, UK) using standard procedures (Pilotti et al, 1997, 1998). Overall, cytogenetic analysis and/or interphase and metaphase FISH were performed in eight out of 21 cases of LL-WDL and in six out of 19 cases of LDSL.

\section{RESULTS}

Table 1 summarizes the main clinical data, treatment and outcome on LL-WDLs. Thirteen out of 21 (61.9\%) patients experienced from one to three recurrences, whereas only one case of recurrence was observed among the LDSLs (case no. 33). Given the uneventful follow-up of the remaining 18 cases a dedicated table has not been produced.

Immunophenotyping (Table 2) shows MDM2/CDK4 expression in 18 of the 21 cases $(85.7 \%)$ and CDK4 immunoreactivity in $100 \%$ of the cases. The analysis of two samples was sufficient to achieve information about the immunophenotypic profile in the majority of the cases. In the three MDM2-CDK4+ cases (Table 2, cases 9, 14 and 16) all available samples were immunostained in order to confirm the null MDM2 immunophenotype.

All LDSL samples analysed turned out to be MDM2CDK4- (Table 3). Tables 2 and 3 and Figure 1A-F summarize 
Table 2 Lipoma-like well differentiated liposarcomas: immunophenotyping, molecular and cytogenetic features (21 cases

\begin{tabular}{|c|c|c|c|c|c|c|c|c|}
\hline \multirow[b]{2}{*}{ Case no. } & \multirow{2}{*}{$\begin{array}{c}\text { Specimens analysed: } \\
\text { primary }(P), \\
\text { recurrences }(R)\end{array}$} & \multicolumn{3}{|c|}{ Immunocytochemistry } & \multicolumn{2}{|c|}{ Southern blot analysis } & \multirow[b]{2}{*}{$\begin{array}{c}\text { Interphase } \\
\text { FISH }\end{array}$} & \multirow[b]{2}{*}{ Cytogenetics } \\
\hline & & a & MDM2 & CDK4 & MDM2 & $C D K 4$ & & \\
\hline 1 & $P$ & $(2 / 7)$ & + & + & + & + & $A$ & \\
\hline 2 & $P$ & $(2 / 6)$ & + & + & + & + & & $48, X Y,+r(12) \times 2 / 2 n+,+d e r(12),+r(12),+d \min$ \\
\hline 3 & $\mathrm{P}$ & $(2 / 9)$ & + & + & + & + & A & \\
\hline 4 & $\mathrm{R}$ & $(2 / 17)$ & + & + & + & + & A & \\
\hline 5 & $\mathrm{R}$ & $(2 / 13)$ & + & + & + & + & & \\
\hline 6 & $\mathrm{R}$ & $(2 / 26)$ & + & + & + & + & A & \\
\hline 7 & $\mathrm{P}$ & $(2 / 11)$ & + & + & + & + & A & $48, X Y,+r(12) \times 2 / 2 n+,+\operatorname{der}(12),+r(12),+d \min$ \\
\hline 8 & $\mathrm{R}$ & $(2 / 23)$ & + & + & + & + & & \\
\hline 9 & $\mathrm{P}$ & $(7 / 7)$ & - & + & + & + & & \\
\hline 10 & $\mathrm{R}$ & $(2 / 7)$ & + & + & & & & \\
\hline 11 & $\mathrm{R}$ & $(2 / 6)$ & + & + & & & & \\
\hline 12 & $\mathrm{R}$ & $(2 / 5)$ & + & + & & & & \\
\hline 13 & $\mathrm{R}$ & $(2 / 6)$ & + & + & & & & \\
\hline 14 & $P$ & $(7 / 7)$ & - & + & & & & $48, X Y,+2 r$ \\
\hline 15 & $\mathrm{P}$ & $(2 / 26)$ & + & + & & & & \\
\hline 16 & $P$ & $(8 / 8)$ & - & + & & & & \\
\hline 17 & $P$ & $(2 / 8)$ & + & + & & & & \\
\hline 18 & $P$ & $(2 / 4)$ & + & + & & & & \\
\hline 19 & $\mathrm{P}$ & $(2 / 4)$ & + & + & & & & \\
\hline 20 & $P$ & $(2 / 9)$ & + & + & & & & \\
\hline 21 & $\mathrm{R}$ & $(2 / 5)$ & + & + & & & & \\
\hline
\end{tabular}

aln brackets: number of samples immunostained for MDM2 and CDK4 by the total of specimens sampled for each tumour. A: features consistent with gene amplification.

Table 3 Lipomas: immunophenotyping, molecular and cytogenetic features (19 cases)

\begin{tabular}{|c|c|c|c|c|c|c|c|c|c|}
\hline \multirow[b]{2}{*}{ Case no. } & \multirow[b]{2}{*}{ Age gender } & \multirow[b]{2}{*}{ Site } & \multirow[b]{2}{*}{ size $(\mathrm{cm})$} & \multicolumn{2}{|c|}{ Immunocytochemistry } & \multicolumn{2}{|c|}{ Southern blot analysis } & \multirow{2}{*}{$\begin{array}{c}\text { Interphase } \\
\text { FISH }\end{array}$} & \multirow{2}{*}{ Cytogenetics } \\
\hline & & & & MDM2 & CDK4 & MDM2 & $C D K 4$ & & \\
\hline 22 & $54 / F$ & Thigh & 18 & - & - & - & - & & \\
\hline 23 & $79 / \mathrm{M}$ & Neck & 7 & - & - & - & - & & \\
\hline 24 & $56 / \mathrm{M}$ & Lower back & 10 & - & - & - & - & TS & \\
\hline 25 & $40 / \mathrm{M}$ & Thigh & 11 & - & - & - & - & TS & \\
\hline 26 & $69 / \mathrm{M}$ & Arm & 7 & - & - & - & - & NE & 46,XY,add (12)(q13) \\
\hline 27 & $67 / \mathrm{M}$ & Thorax region & 10 & - & - & - & - & & \\
\hline 28 & $66 / \mathrm{M}$ & Abdominal wall & 30 & - & - & - & - & & \\
\hline 29 & $39 / \mathrm{M}$ & Thorax region & 17 & - & - & & & & \\
\hline 30 & $52 / \mathrm{M}$ & Thigh & 7 & - & - & & & & \\
\hline 31 & $57 / F$ & Abdominal wall & 13 & - & - & & & & \\
\hline 32 & $66 / \mathrm{M}$ & Lower back & 13 & - & - & & & & \\
\hline 33 & $76 / \mathrm{M}$ & Abdominal wall & 10 & - & - & & & & \\
\hline 34 & $31 / \mathrm{M}$ & Thorax wall & 7 & - & - & & & & \\
\hline 35 & $64 / F$ & Shoulder & 9 & - & - & & & & \\
\hline 36 & $59 / \mathrm{M}$ & Lower back & 11 & - & - & & & & \\
\hline 37 & $68 / \mathrm{M}$ & Shoulder & 12 & - & - & & & & \\
\hline 38 & $56 / F$ & Thorax region & 7 & - & - & & & & \\
\hline 39 & $53 / F$ & Shoulder & 10 & - & - & & & & \\
\hline 40 & $59 / \mathrm{M}$ & Thigh & 21 & - & - & & & TS & $46, X Y t(6 ; 18)(q 13-14 ; q 21)$ \\
\hline
\end{tabular}

$\mathrm{NE}=$ not evaluable; $\mathrm{TS}=$ two signals.

immunophenotypic, genotypic and cytogenetic results. In keeping with immunophenotypic findings amplification of both MDM2 and CDK4 genes was observed in the nine LL-WDLs and no abnormality of the two genes was observed in the seven LDSLs analysed by Southern blot. Interestingly, case no. 9, categorized routinely on morphologic grounds as lipoma and reported as MDM2-negative in a previous investigation (Pilotti et al, 1997), showed CDK4 immunoreactivity (Figure 1C) and CDK4 as well 
A

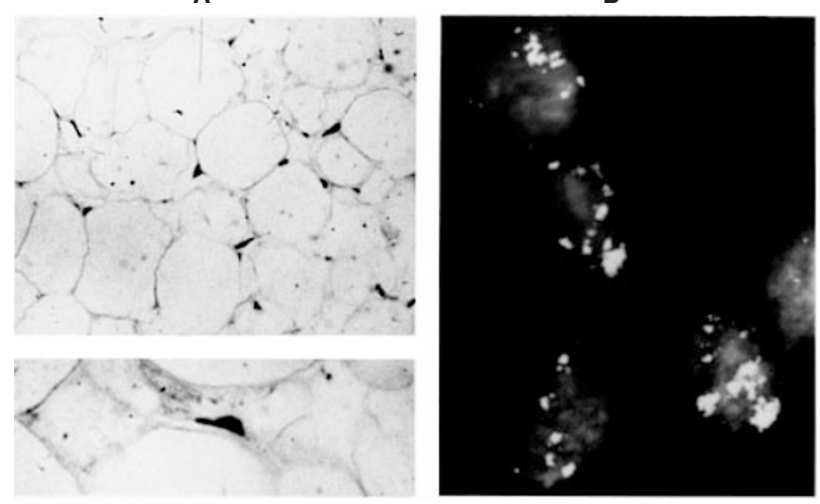

Case 8

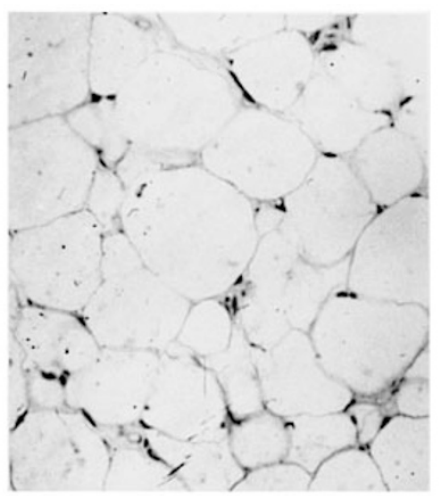

Case 9
D

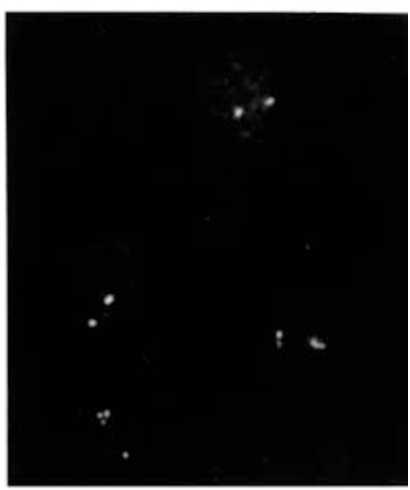

Case 24

E

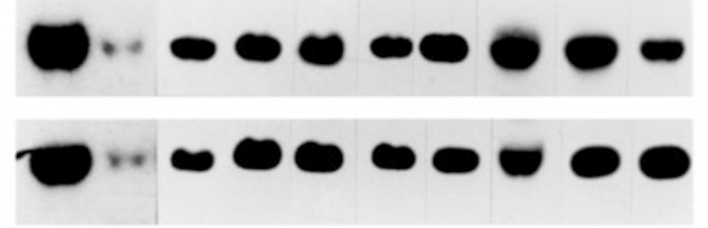

MDM2

F

CDK4
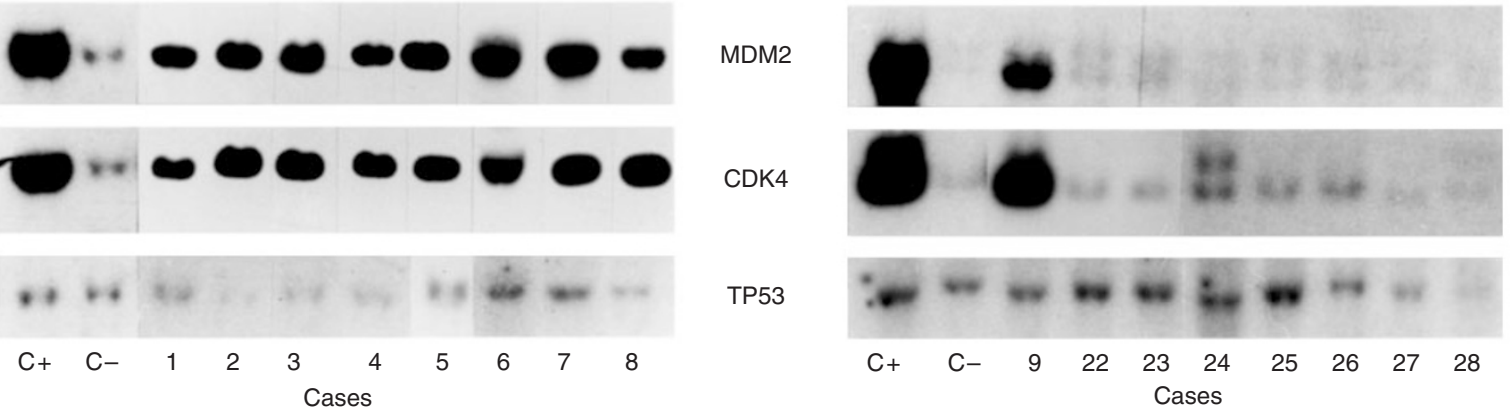

TP53

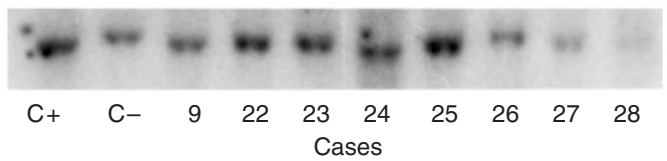

Figure 1 (A) and inset: mdm2 expression, and (B) gene amplification by FISH, in one of the LL-WDL cases (case no. 8). (C) cdk4 immunoreactivity, in case no. 9 (previously classified as LDSL) null for mdm2 but showing coamplification at MDM2 and CDK4 genes by Southern blot (see below). (D) FISH showing two normal signals in one of the LDSL cases (case no. 24). (E) Southern blot analysis of MDM2 and CDK4 amplification in eight cases of LL-WDL. Hybridization with MDM2 or CDK4 probe reveals amplification of both genes in the tumour DNA of all cases. (F) Southern blot hybridization of 1 LL-WDL (previously classified as LDSL, case no. 9) and seven cases of LDSL. None of the LDSLs show amplification of MDM2 and CDK4 while the two genes are coamplified in the LL-WDL. As a control for the loading amount of DNA the blots in E and F were hybridized with a TP53 probe. C+: SJSA-1 osteosarcoma cell line positive for MDM2 and CDK4 amplification. C-: normal peripheral blood cells. The numbers on the bottom of the blots are in accordance with Tables 2 and 3

as MDM2 gene amplification (Figure 1F) despite MDM2 null immunophenotype. In light of these findings the case, which since the time of the first categorization showed no completely convincing benign features, was reconsidered as possible LL-WDL and included in Table 1.

FISH was successfully applied in the five cases of LL-WDL and in three out of four cases of LDSL. Nuclei obtained from the LL-WDL cases showed an amplification level ranging from eight to 15 signals (Figure 1B). Although FISH cannot demonstrate that the amplified gene is $M D M 2$ (since the probe covered MDM2, SAS and GLI sequences), this assumption is supported by the immunostaining (Figure 1A) and Southern blot results obtained with the $M D M 2$-specific probe (Figure 1E). By contrast, nuclei from LDSL showed two normal signals corresponding to the two copies of the region (1D). Karyotypic analysis showed the presence of ring chromosomes in three LL-WDL cases analysed; two of them (case no. 2 and no. 14) also showed the presence of a minor clone (10\% of the total metaphases), that contained ring chromosomes, giant markers and double minutes. In these two cases FISH experiments with a whole chromosome 12 probe completely painted the ring chromosomes of the major clone, and the ring chromosomes, the double minutes and part of the giant markers of the minor clone. A translocation with a breakpoint at band q13 of chromosome 12 was found in case no. 26 of LDSL, and a novel translocation $\mathrm{t}(6 ; 18)(\mathrm{q} 13-14 ; \mathrm{q} 21)$ was found in case no. 40 of LDSL.

\section{DISCUSSION}

On cytogenetic grounds, about two-thirds of ordinary lipomas and most WDLs share aberrations in the chromosome 12q13-15 segment (Mandahl et al, 1996). However, in lipomas the majority of these aberrations are consistent with the creation of chimaeric genes made up of a fusion of the HMG1-C gene in 12q15 with multiple partners, although the LPP (lipoma preferred partner) gene, at 3q27-28, is preferentially involved (Petit et al, 1996). On the other hand, in WDLs the aberrations of chromosome $12 \mathrm{q}$ are represented by the amplification of genes spanning the $13 q-15 q$ region (Berner et al, 1997; Dei Tos and Dal Cin, 1997). Assuming that these findings represent two different transformation pathways, and taking into account that MDM2 and CDK4 gene amplification parallels the presence of ring chromosomes as well as MDM2 and CDK4 protein overexpression (Pilotti et al, 1997, 1998), it is reasonable to assume that immunophenotyping will assist in the differential diagnosis between LL-WDL and LDSL. The present data confirm this assumption that, in turn, makes immunophenotype more consistent with biology than morphology. Similar results have recently been observed using different, less easily handled and not always applicable methodologic approaches, such as classical cytogenetic methods and comparative genomic hybridization (CGH) (Suijkerbuijk et al, 1994; Mandahl et al, 1996; Szymanska et al, 1997). 
Support to our immunophenotypic results is provided by the molecular and cytogenetic data which fitted with the immunophenotypic information in all the examined cases. For the MDM2 gene, the Southern blot data were further confirmed by FISH which showed amplification in the 5 LL-WDL analysed. By contrast, FISH revealed only two signals in the three LDSLs successfully analysed. Moreover, in one of these three cases of lipoma (case no. 26) the diagnosis was further supported by the presence of a translocation with a breakpoint at q13 of chromosome 12, a cytogenetic feature characteristic of lipoma (Heim and Mitelman, 1995), and a novel translocation $\mathrm{t}(6 ; 18)(\mathrm{q} 13-14 ; \mathrm{q} 21)$ was found in a second case. Even though rearrangement of 12q13-14 and $6 p$ are the most frequently found in lipoma, other observations which do not involve these chromosome arms have been reported (Willen et al, 1998). The finding that the MDM2 antibody failed to decorate tumour cells in two cases of LL-WDL (cases 14 and 16 respectively), points out the value of $C D K 4$ gene assessment in differential diagnosis, and reconfirms that even amplification excluding MDM2 may contribute to transformation (Pilotti et al, 1998). It is rather unlikely, in fact, that immunostaining failure be ascribed to cellular variation as immunostaining was performed in all samples. However, this possibility cannot be completely excluded in case no. 9 because of the discrepancy between immunochemical and molecular analyses regarding the MDM2 amplification which, on the other hand, could suggest that an MDM2 gene amplification can occur without the expression of the relative product.

In conclusion our results support the notion that MDM2 and CDK4 immunophenotyping may represent a valuable ancillary procedure in the assessment of arguable LDSL cases. This diagnostic approach will also clarify if retroperitoneal lipoma represents an anecdotal occurrence or a reality (DeWeerd and Dockerty, 1952).

\section{ACKNOWLEDGEMENTS}

This work was supported by grant from AIRC (Associazione Italiana per la Ricerca sul Cancro). We are grateful to Mario Azzini for professionally preparing the illustrations and to Alda Tosi for secretarial assistance.

\section{REFERENCES}

Berner J-M, Meza-Zepeda LA, KoolsPFJ, Forus A, Schoenmakers EFPM, Van de Ven WJM, Fodstad Ø and Myklebost O (1997) HMGIC, the gene for an architectural transcription factor, is amplified and rearranged in a subset of human sarcomas. Oncogene 14: 2935-2941

Dal Cin P, Kools P, Sciot R, De Wever I, Van Damme B, Van de Ven W and Van Den Berghe H (1993) Cytogenetic and fluorescence in situ hybridization investigation of ring chromosomes characterizing a specific pathologic subgroup of adipose tissue tumors. Cancer Genet Cytogenet 68: 85-90

Dei Tos AP and Dal Cin P (1997) The role of cytogenetics in the classification of soft tissue tumours. Virchows Arch 431: 83-94

DeWeerd JH and Dockerty MB (1952) Lipomatous retroperitoneal tumors. Am J Surg 84: 397-407

Evans HL (1988) Liposarcoma and atypical lipomatous tumors: a study of 66 cases followed for a minimum of 10 years. Surg Pathol 1: 41-54

Fletcher CDM, Akerman M, Dal Cin P, de Wever I, Mandhal N, Mertens F, Mitelman F, Rosai J, Rydholm A, Sciot R, Tallini G, van den Berghe H, van de Ven W, Vanni R and Willen H (1996) Correlation between clinicopathological features and karyotype in lipomatous tumors. A report of 178 cases from the chromosomes and morphology (CHAMP) collaborative study group. Am J Pathol 148: 623-630

Forus A, Flørenes VA, Maelandsmo GM, Meltzer PS, Fodstad Ø and Myklebost O (1993) Mapping of amplification units in the q13-14 region of chromosome 12 in human sarcomas: some amplica do not include MDM2. Cell Growth Differ 4: $1065-1070$
Heim S and Mitelman F (1995) Cancer cytogenetics. Chromosomal and molecular genetic aberrations of tumor cells. 2nd edn, pp. 484-489. Wiley-Liss: New York

Hunter T and Pines J (1994) Cyclins and cancer. II: cyclin D and CDK inhibitors come of age. Cell 79: $573-582$

Khatib ZA, Matsushime H, Valentine M, Shapiro DN, Sherr CJ and Look AT (1993) Coamplification of the CDK4 gene with MDM2 and GLI in human sarcomas. Cancer Res 53: 5535-5541

Leach FS, Tokino T, Meltzer P, Burrell M, Oliner JD, Smith S, Hill DE, Sidransky D, Kinzler KW and Vogelstein B (1993) p53 mutation and MDM2 amplification in human soft tissue sarcomas. Cancer Res 53: 2231-2234

Lichter P, Chang Tang C, Call K, Hermanson G, Evans GA, Housman D and Ward DC (1990) High resolution mapping of human chromosome 11 by in situ hybridization with cosmid clones. Science 247: 64-67

Mandahl N, Akerman M, Aman P, Dal Cin P, De Wever I, Fletcher CDM, Mertens F, Mitelman F, Rosai J, Rydholm A, Sciot R, Tallini G, van den Berghe H, Van de Ven W, Vanni R and Willen H (1996) Duplication of chromosome segment $12 \mathrm{q} 15-24$ is associated with atypical lipomatous tumors: a report of the CHAMP collaborative study group. Int J Cancer 67: 632-635

Mentzel T and Fletcher CDM (1995) Lipomatous tumours of soft tissues: an update. Virchows Arch 427: 353-363

Mezzelani A, Sozzi G, Pierotti MA and Pilotti S (1996) Rapid differential diagnosis of myxoid liposarcoma by fluorescence in situ hybridization on cytological preparations. J Clin Pathol: Mol Pathol 49: M308-M309

Nilbert M, Rydholm A, Willen H, Mitelman F and Mandahl N (1994) MDM2 gene amplification correlates with ring chromosomes in soft tissue tumors. Genes Chrom Cancer 9: 261-265

Pedeutour F, Suijkerbuijk RF, Van Gaal J, Van de Klundert W, Coindre J-M, Van Haelst A, Collin F, Huffermann K and Turc-Carel C (1993) Chromosome 12 origin in rings and giant markers in well-differentiated liposarcoma. Cancer Genet Gytogenet 66: 133-134

Petit MMR, Mols R, Schoenmakers EF, Mandahl N and Van de Ven WJ (1996) LPP, the preferred fusion partner gene at HMGIC in lipomas, is a novel member of the LIM protein gene family. Genomics 36: 118-129

Pilotti S, Della Torre G, Lavarino C, Di Palma S, Sozzi G, Minoletti F, Rao S, Pasquini G, Azzarelli A, Rilke F and Pierotti MA (1997) Distinct mdm2/p53 expression patterns in liposarcoma subgroups: implications for different pathogenetic mechanisms. J Pathol 181: 14-24

Pilotti S, Della Torre G, Lavarino C, Sozzi G, Minoletti F, Vergani B, Azzarelli A, Rilke F and Pierotti MA (1998) Molecular abnormalities in liposarcoma: role of MDM2 and CDK4-containing amplicons at 12q13-22. J Pathol 185: $188-190$

Rosai J, Akerman M, Dal Cin P, DeWever I, Fletcher CDM, Mandhal N, Mertens F, Mitelman F, Rydholm A, Sciot R, Tallini G, Van Den Berghe H, Van De Ven W, Vanni R and Willen H (1996) Combined morphologic and karyotypic study of 59 atypical lipomatous tumors. Evaluation of their relationship and differential diagnosis with other adipose tissue tumors (a report of the CHAMP study group). Am J Surg Pathol 20: 1182-1189

Schoenmakers EFPM, Wanschura S, Mols R, Bullerdiek J, Van den Berghe H and Van de Ven WJM (1995) Recurrent rearrangements in the high mobility group protein gene, HMGI-C, in benign mesenchymal tumors. Nat Genet 10: 436-444

Smith SH, Weiss SW, Jankowski SA, Coccia MA and Meltzer PS (1992) SAS amplification in soft tissue sarcomas. Cancer Res 52: 3746-3749

Suijkerbuijk RT, Olde Weghuis DEM, Van Den Berg M, Pedeuour F, Forus A, Myklebost O, Glier C, Turc-Carel C and Geurts van Kessel A (1994) Comparative genomic hybridization as a tool to define two distinct chromosome 12 amplification units in well-differentiated liposarcomas. Genes Chromosomes Cancer 9: 292-295

Szymanska J, Virolainen M, Tarkkanen M, Wiklund T, Asko-Seljavaara S, Tukiainen E, Elomaa I, Blomqvist C and Knuutila S (1997) Overrepresentation of 1q21-23 and 12q13-21 in lipoma-like liposarcomas but not in benign lipomas: a comparative genomic hybridization study. Cancer Genet Cytogenet 99: 14-18

Tkachenko A, Ashar HR, Meloni AM, Sandberg AA and Chada KK (1997) Misexpression of disrupted HMGI architectural factors activates pathways of tumorigenesis. Cancer Res 57: 2276-2280

Willen H, Akerman M, Dal Cin P, De Wever I, Fletcher CDM, Mandahl N, Mertens F, Mitelman F, Rosai J, Rydholm A, Sciot R, Tallini G, Van Den Berghe H and Vanni R (1998) Comparison of chromosomal patterns with clinical features in 165 lipomas: a report of the CHAMP study group. Cancer Genet Cytogenet 102: $46-49$

Zauberman A, Flusberg D, Haupt Y, Barak Y and Oren M (1995) A functional p53-responsive intronic promoter is contained within the human mdm2 gene. Nucleic Acids Res 23: 2584-2592 